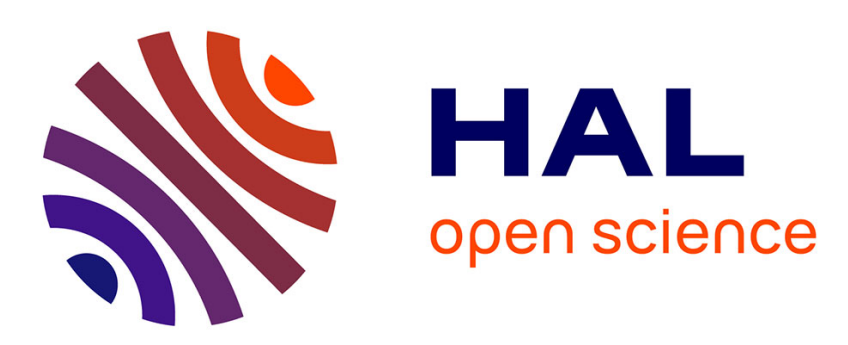

\title{
Changes in mitochondrial gene and protein expression in grass shrimp, exposed to chronic hypoxia
}

\author{
Marius Brouwer, Nancy J. Brown-Peterson, Thea Hoexum-Brouwer, Steve
}

Manning, Nancy Denslow

\section{To cite this version:}

Marius Brouwer, Nancy J. Brown-Peterson, Thea Hoexum-Brouwer, Steve Manning, Nancy Denslow. Changes in mitochondrial gene and protein expression in grass shrimp, , exposed to chronic hypoxia. Marine Environmental Research, 2008, 66 (1), pp.143. 10.1016/j.marenvres.2008.02.046 . hal-00563017

\section{HAL Id: hal-00563017 https://hal.science/hal-00563017}

Submitted on 4 Feb 2011

HAL is a multi-disciplinary open access archive for the deposit and dissemination of scientific research documents, whether they are published or not. The documents may come from teaching and research institutions in France or abroad, or from public or private research centers.
L'archive ouverte pluridisciplinaire HAL, est destinée au dépôt et à la diffusion de documents scientifiques de niveau recherche, publiés ou non, émanant des établissements d'enseignement et de recherche français ou étrangers, des laboratoires publics ou privés. 


\section{Accepted Manuscript}

Changes in mitochondrial gene and protein expression in grass shrimp, Palaemonetes pugio, exposed to chronic hypoxia

Marius Brouwer, Nancy J. Brown-Peterson, Thea Hoexum-Brouwer, Steve Manning, Nancy Denslow

PII:

S0141-1136(08)00064-0

DOI: 10.1016/j.marenvres.2008.02.046

Reference: MERE 3216

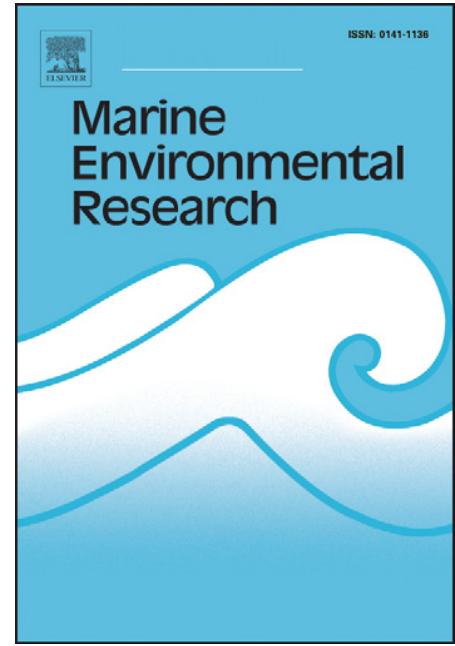

To appear in:

Marine Environmental Research

Please cite this article as: Brouwer, M., Brown-Peterson, N.J., Hoexum-Brouwer, T., Manning, S., Denslow, N., Changes in mitochondrial gene and protein expression in grass shrimp, Palaemonetes pugio, exposed to chronic hypoxia, Marine Environmental Research (2008), doi: 10.1016/j.marenvres.2008.02.046

This is a PDF file of an unedited manuscript that has been accepted for publication. As a service to our customers we are providing this early version of the manuscript. The manuscript will undergo copyediting, typesetting, and review of the resulting proof before it is published in its final form. Please note that during the production process errors may be discovered which could affect the content, and all legal disclaimers that apply to the journal pertain. 


\title{
Changes in mitochondrial gene and protein expression in grass
}

\author{
shrimp, Palaemonetes pugio, exposed to chronic hypoxia
}

\section{Marius Brouwer ${ }^{a^{*},}$ Nancy J. Brown-Peterson ${ }^{\text {a }}$, Thea Hoexum-Brouwer ${ }^{\text {a }}$, Steve Manning a, Nancy Denslow}

\begin{abstract}
${ }^{a}$ Department of Coastal Sciences, The University of Southern Mississippi, PO Box 7000, Ocean Springs, MS, 39566 USA and ${ }^{b}$ Department of Physiological Sciences and Center for Environmental and Human Toxicology, University of Florida, PO Box 110885, Gainesville, FL, 32610, USA
\end{abstract}

\begin{abstract}
Spatial and temporal increases of hypoxia in estuaries are of major environmental concern. Since mitochondria consume most of the oxygen in the cell, we examined the potential role of mitochondrial gene and protein expression in adaptation to chronic hypoxia in the grass shrimp Palaemonetes pugio. Grass shrimp were exposed to DO levels slightly above and below the critical $p \mathrm{O}_{2}, 1.8 \mathrm{mg} / \mathrm{L}$, for $P$. pugio, and hypoxia-induced alterations in gene expression were screened using custom cDNA macroarrays. Mitochondrial gene expression was not affected by exposure to moderate hypoxia $(2.5 \mathrm{mg} / \mathrm{L} \mathrm{DO})$. However, chronic exposure to severe hypoxia (1.5 mg/L DO) for 7 days resulted in an increase of transcription of genes present in the mitochondrial genome (including $16 \mathrm{~S} r R N A$ and $C \operatorname{cox} 1$ ), together with up-regulation of genes
\end{abstract}


involved in Fe/heme metabolism. This pattern was completely reversed by day 14, when a significant down-regulation of these genes was observed. Separating mitochondrial proteins in 2 dimensions by IEF and reverse phase chromatography, followed by LC/MS/MS of differentially expressed proteins, showed cytochrome c oxidase subunit 2, encoded by Ccox 2, was downregulated after $12 \mathrm{~d}$ exposure to severe hypoxia. It appears therefore that decreases in mitochondrial Ccox gene transcription result in decreased mitochondrial Ccox protein synthesis. These results suggest that mitochondrial genes and proteins show promise as molecular indicators of exposure to hypoxia.

Keywords: Hypoxic stress; cDNA array; Mitochondrial genes; Mitochondrial proteins; Crustacea

*Corresponding author: Tel. 228-872-4294, fax 228-872-4204

Email address: marius.brouwer@usm.edu (M. Brouwer) 
Bottom water hypoxia and anoxia are major factors responsible for declines in habitat quality and harvestable resources in estuarine ecosystems (Diaz and Rosenberg, 1995; Buzelli et al., 2002). Hypoxia can lead to rapid as well as long-term cellular, physiological and behavioral changes in a variety of organisms. Differential gene expression in fishes reflects the metabolic roles of tissues during hypoxia exposure (Gracey et al., 2001; Ton et al., 2003). Hypoxiaresponsive genes and proteins have recently been identified in blue crab, Callinectes sapidus (Brown-Peterson et al., 2005) and the grass shrimp Palaemonetes pugio (Brouwer et al., 2007). Since mitochondria consume most of the oxygen in the cell, the objective of this study was to examine the potential role of mitochondrial gene and protein expression in adaptation to chronic hypoxia by grass shrimp.

The critical $p \mathrm{O}_{2}(p$ Crit) at which aerobic metabolism becomes limited in grass shrimp is 30-35 torr, or $~ 1.8 \mathrm{mg} / \mathrm{mL}$ (Cochran and Burnett, 1996). We therefore exposed female grass shrimp (intermolt, 27-36 mm), held individually in mesh containers in $35 \mathrm{~L}$ glass aquaria ( $\mathrm{N}=25$ containers/aquaria), to moderate $(2.5 \mathrm{mg} / \mathrm{L} \mathrm{DO}$, slightly above $p$ Crit $)$ or severe $(1.5 \mathrm{mg} / \mathrm{L} \mathrm{DO}$, slightly below $p$ Crit) chronic hypoxia or normoxia (8 mg/L DO) for 61 days in an intermittent flow-through system; oxygen levels were controlled by bubbling nitrogen into a holding tank as previously described (Brouwer et al., 2007). Temperature $\left(27 \pm 1^{\circ} \mathrm{C}\right)$ and salinity $(15 \mathrm{psu})$ were held constant. Shrimp were sampled at 3, 7, 14 and 26-61 days from normoxic and hypoxic tanks for gene expression and at $12 \mathrm{~d}$ for protein expression $(\mathrm{N}=10$ for each treatment and time point). The thorax was stored in RNAlater for RNA extraction; mitochondria were prepared immediately from muscle tissue for protein analysis using a Mitochondrial Isolation Kit (PIERCE, Rockford, IL). 
To measure changes in gene expression, 77 potentially hypoxia-responsive grass shrimp genes, identified through suppression subtractive hybridization, were PCR amplified and spotted in duplicate onto neutral nylon macroarrays as previously described (Brouwer et al., 2007). Hepatopancreatic RNA was extracted using Stat-60 (Tel-Test, Friendswood, TX), transcribed into radiolabeled cDNA, hybridized to the membranes and spot intensities were measured following Larkin et al. (2003). Intensity values were log base 2 transformed and normalized to $\alpha$ tubulin. Fold change in gene expression was calculated from the mean of normalized values of hypoxic and normoxic shrimp for each time point, and tested for significance $(p<0.05)$ using the Student t-test.

Mitochondrial proteins from normoxic and $12 \mathrm{~d}$ hypoxic shrimp were separated in 2 dimensions using the ProteomeLab PF2D System (Beckman Coulter, Fullerton, CA). Differentially expressed protein fractions were digested with trypsin and analyzed by Proteomic Research Services, Inc. (Ann Arbor, MI) using LC/MS/MS on a Finnigan ${ }^{\mathrm{TM}}$ LTQ $^{\mathrm{TM}}$. Monoisotopic masses from the tryptic digests were used to identify the corresponding proteins using the MASCOT search algorithm (www.matrixscience.com).

Moderate chronic hypoxia, at DO levels above $p$ Crit, had no effect on mitochondrial gene transcription. In contrast, significant changes were observed in expression of mitochondrial genes at days 7, 14 and 26-61 (but not at day 3) in grass shrimp exposed to severe chronic hypoxia, at DO levels below $p$ Crit (Table 1). At day 3 a temporary up-regulation of hemocyanin occurred (Brouwer et al., 2007). Cytochrome c oxidase I (Ccoxl) and 16S rRNA were significantly up-regulated after $7 \mathrm{~d}$ exposure. Cytochromes are Fe/heme proteins, and genes encoding heme binding protein and ferritin were also significantly up-regulated. After 14d a reversal of this gene expression pattern was observed, with a significant down-regulation of 
Ccoxl, cytochrome c oxidase III (Ccox3), cytochrome b (cytb), 16S rRNA, the heme binding protein, and ferritin. Prolonged, 26-61d exposure to severe hypoxia resulted in the continued significant down-regulation of $c y t b$ and $C \operatorname{cox} 3$ (Table 1). Similar down-regulation of genes in the electron transport chain occurred in zebrafish exposed to long-term, $3 \mathrm{wk}$, severe $(\sim 1.8 \mathrm{mg} / \mathrm{L})$ hypoxia (van der Meer et al., 2005). Interestingly, mRNA levels of hypoxia-inducible factor $(\mathrm{HIF}-1 \alpha)$ remained unaltered in grass shrimp during moderate and severe hypoxia exposures $(\mathrm{Li}$ and Brouwer, 2007).

LC/MS/MS identified a 30 amino acid peptide in $12 \mathrm{~d}$ control mitochondria that was lacking in 12 d hypoxic mitochondria, whose sequence was $100 \%$ homologous to cytochrome c oxidase subunit 2 (Ccox 2) from insects. The down-regulation of mitochondrial Ccox gene expression after $14 \mathrm{~d}$ exposure to severe hypoxia was thus mirrored by a decrease in Ccox 2 protein synthesis after a $12 \mathrm{~d}$ exposure to severe chronic hypoxia (Fig. 1). In conclusion, grass shrimp appear to adapt to long-term severe hypoxia by conserving energy through downregulation of mitochondrial protein synthesis, which suggests that expression levels of genes encoding proteins involved in electron transport may be useful molecular indicators of exposure to long-term severe hypoxia.

\section{Acknowledgements}

C. King assisted with sampling and V. Patel performed the macroarray hybridizations and analyses. This research is supported by grants from US EPA (R82945801) and NOAA (NAO3NOS4260216). 


\section{References}

Brouwer, M., Brown-Peterson, N.J., Larkin, P., Patel, V., Denslow, N., Manning, S., et al. (2007). Journal of Experimental Marine Biology and Ecology, 341, 16-31.

Brown-Peterson, N.J., Larkin, P., Denslow, N., King, C., Manning, C., and Brouwer, M. (2005). Marine Ecology Progress Series, 286, 203-215.

Buzzelli, C.P., Luettich, R.A., Powers, S.P., Peterson, C.H., McNinch, J.E., Pinckney, J.L. et al. (2002). Marine Ecology Progress Series, 230, 103-112.

Cochran, R.E., and Burnett, L.E. (1996). Journal of Experimental Marine Biology and Ecology, $195,125-144$.

Diaz, R.J., and Rosenberg, R. (1995). Oceanography and Marine Biology Annual Review, 33, 245-303.

Gracey, A.Y., Troll, J.V., and Somero, G.N. (2000). Proceedings of the National Academy of Sciences, USA 98, 1991-1998.

Larkin, P., Folmar, L.C., Hemmer, M.J., Poston, A.J., and Denslow, N.D. (2003). Environmental Health Perspectives, Toxicogenomics, 111, 839-846.

Li, T., and Brouwer, M. (2007). Comparative Biochemistry and Physiology Part B, 147: 11-19. van der Meer, D.L.M., van den Thillart, G.E.E.J.M., Witte, F., de Bakker, M.A.G., Besser, J., Richardson, M.K., et al. (2005). American Journal of Physiology - Regulatory, Integrative and Comparative Physiology, 289:1512-1519.

Ton, C., Stamatiou, D., and Liew, C.-C. (2003). Physiological Genomics, 13, 97-106. 
Table 1.

Fold-change values (hypoxic/normoxic) of mitochondrial genes in grass shrimp $(\mathrm{N}=8-10)$ exposed to severe $(1.5 \mathrm{mg} / \mathrm{L} \mathrm{DO})$ chronic hypoxia at various time points. * significant fold change (t-test, $p<0.05)$. Positive fold changes indicate up-regulation, negative fold changes indicate down-regulation.

\begin{tabular}{|l|l|l|l|l|}
\hline Gene & $\mathbf{3}$ days & $\mathbf{7}$ days & $\mathbf{1 4}$ days & $\mathbf{2 6 - 6 1}$ days \\
\hline $16 \mathrm{~S}$ rRNA & 1.36 & $5.35^{*}$ & $-6.00^{*}$ & 1.45 \\
\hline Cytochrome c oxidase I (Ccoxl) & 1.10 & $2.58^{*}$ & $-3.20^{*}$ & 0.35 \\
\hline Cytochrome c oxidase III (Ccox3) & 1.18 & 1.08 & $-4.00^{*}$ & $-2.80^{*}$ \\
\hline Cytochrome b (cytb) & 1.54 & 1.65 & $-3.20^{*}$ & $-2.20^{*}$ \\
\hline Heme binding protein & 1.64 & $3.56^{*}$ & -1.5 & -0.10 \\
\hline Ferritin & $2.33^{*}$ & $7.28^{*}$ & -3.808 & 1.07 \\
\hline
\end{tabular}




\section{Figure Caption}

Fig 1. Muscle mitochondrial proteins of control grass shrimp, and shrimp exposed to $1.5 \mathrm{mg} / \mathrm{L}$ DO for 12 days, were separated in 2 dimensions on a ProteomeLab PF 2D system. The left panel (normoxic control) shows the reverse phase elution profile of the fraction that elutes in the first dimension between $\mathrm{pH}$ 4.52-4.82 (fraction 23). The right panel (hypoxic treatment) shows the reverse phase elution profile of the corresponding fraction; the same amount of protein was applied to the first dimension column. The middle panel shows the difference between the two profiles. The marked fraction (present in control but not in treatment) was digested with trypsin and analyzed by LC/MS/MS. A peptide (IILPMNTQIRMIVSAADVLHSWTIPSLGVK) was identified corresponding to cytochrome c oxidase subunit 2 (Ccox2). The same peptide was identified in a duplicate sample. 


\section{ACCEPTED MANUSCRIPT}
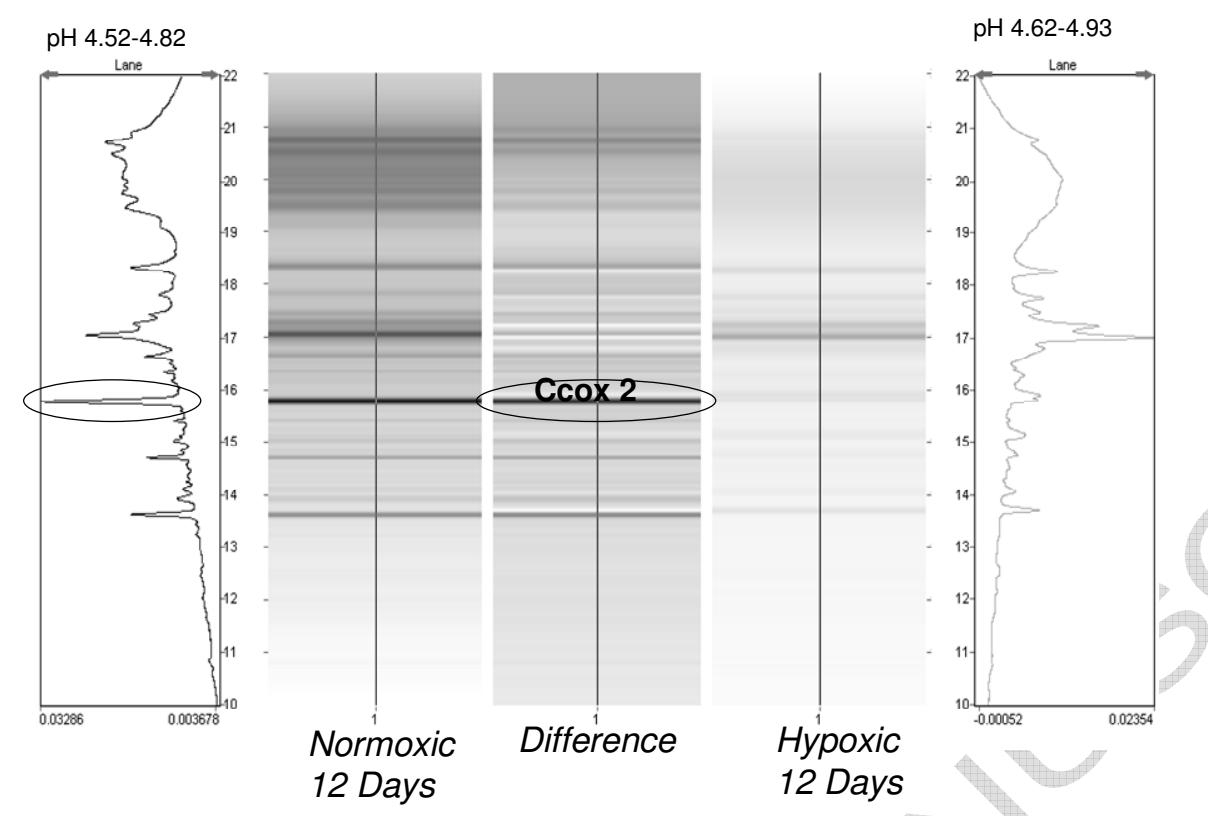

Figure 1 